\begin{tabular}{|l|c|c|c|c|}
\hline $\begin{array}{l}\text { Cuadernos de Investigación Geográfica } \\
\text { Geographical Research Letters }\end{array}$ & 2019 & N $^{\circ} 45(1)$ & pp. 287-308 & eISSN 1697-9540 \\
\hline
\end{tabular}

\title{
IMPACT OF MECHANISATION ON SOIL LOSS IN TERRACED VINEYARD LANDSCAPES
}

\author{
A. PIJL ${ }^{1 *}$, P. BARNEVELD ${ }^{2}$, L. MAURI ${ }^{1}$, E. BORSATO $^{1}$, \\ S. GRIGOLATO ${ }^{1}$, P. TAROLLI ${ }^{1}$ \\ ${ }^{1}$ Department of Land, Environment, Agriculture and Forestry, University of Padova, Italy. \\ ${ }^{2}$ Soil Physics and Land Management Group, Wageningen University, The Netherlands.
}

\begin{abstract}
Soil loss poses a threat to hilly and mountainous areas, particularly where local economies strongly depend on agricultural production. Among agricultural landscapes, vineyards are responsible for the highest erosion rates, particularly in steep-slope landscapes. The impact of vineyard mechanisation on soil loss is only marginally explored in published literature. This study provides an estimation of the annual soil loss rate by application of the Revised Universal Soil Loss Equation (RUSLE) in 24 terraced vineyards located in north-eastern Italy. Field observations showed that 13 vineyards consisted of fully mechanised fields, 5 vineyards had no form of mechanisation, while in 6 vineyards a mixture of practices was found. Soil erodibility ( $K$ factor) was derived for these practices (based on soil characteristics and varying degrees of compaction), while slope length and steepness (LS factors) were calculated from a 1-m LiDAR-based DTM, and remaining factors were based on datasets by the European Soil Data Centre. Mechanised fields showed 29\% higher erosion rates than non-mechanised fields (respectively 53.9 and $69.5 t h a^{-1} y^{-1}$ ), although this is not statistically significant. Still, the direct impact of mechanisation is underestimated in this comparison, due to the predominant steep slopes in the manually cultivated fields. Furthermore, estimated soil loss from mechanised fields in addition to mechanised paths and roads is significantly higher by $37 \%$ than nonmechanised fields. This study thus offers an indication of how machinery and related soil compaction and transformation of terraces and infrastructure, increases soil loss risk.
\end{abstract}

\section{Impacto de la mecanización en la pérdida de suelo en viñedos aterrazados}

RESUMEN. La pérdida de suelo amenaza las áreas de montaña, particularmente donde la economía local depende fuertemente de la agricultura. Los viñedos muestran las tasas de erosión más altas especialmente en los paisajes que presentan pendientes escarpadas. El impacto de la mecanización en los viñedos en la pérdida de suelo ha sido escasamente investigado. Este estudio provee una estimación de la tasa de pérdida de suelo anual utilizando 
la Revised Universal Soil Loss Equation (RUSLE) en 24 terrazas de viñedos situadas en el noreste de Italia. Las observaciones de campo mostraron que 13 viñedos estaban completamente mecanizados, 5 viñedos no presentaron ninguna forma de mecanización, y 6 viñedos presentaron prácticas mixtas. La erodibilidad del suelo (factor $K$ ) fue derivada de las prácticas (basada en el grado de compactación), mientras que la longitud y el grado de la pendiente (factor LS) fueron calculados a partir de MDT 1-m basado en LiDAR, y los factores restantes fueron obtenidos de las bases de datos de la European Soil Data Centre. Las tasas de erosión en los terrenos mecanizados fueron un 29\% mayor que las de los terrenos no mecanizados (53.9 y $69.5 \mathrm{tha}^{-1}$ año ${ }^{-1}$, respectivamente), sin embargo, no fue estadísticamente significativo. No obstante, el impacto directo de la mecanización es subestimada en esta comparación, debido a la pendiente escarpada en los terrenos cultivados manualmente. Adicionalmente, la estimación de la pérdida de suelo combinada con la mecanización de senderos, caminos y terrenos es significativamente mayor con un $37 \%$ más de pérdida que los terrenos no mecanizados. Este estudio ofrece una indicación de cómo la compactación del suelo por la maquinaria y la transformación de las terrazas e infraestructura incrementa el riesgo de la pérdida de suelo.

Key words: RUSLE, erosion, mechanization, vineyard terraces, compaction, Northeastern Italy.

Palabras clave: RUSLE, erosión, mecanización, viñedos en terrazas, compactación, Noroeste de Italia.

Received: 4 October 2018

Accepted: 19 December 2018

*Corresponding author: Anton Pijl, Department of Land, Environment, Agriculture and Forestry, University of Padova, Italy. E-mail address: anton.pijl@phd.unipd.it.

\section{Introduction}

The impact of agricultural mechanisation on land degradation is well known and documented. The increased pressure of heavy machinery can cause topsoil compaction or a subsoil hard pan directly under the ploughing depth, inducing run-off, soil loss and waterlogging (Batey, 2009; Chan et al., 2006; Schjønning et al., 2002; Stoate et al., 2001; Tarolli et al., 2019). Compaction can be reverted naturally, e.g. by soil flora and fauna (Makeschin, 1997; Marinissen, 1992), but tillage has shown to be destructive for biodiversity in the soil (Baguette and Hance, 1997; Carcamo, 1995; Schrader and Lingnau, 1997; Schreck et al., 2012) or on the surface (Chamberlain et al., 2000). Mechanical tillage for weed control is common in perennial production systems, even if vegetative cover is highly favourable for maintaining soil organic matter and soil permeability, hence mitigating soil erosion rates (Gyssels et al., 2005; Lipecki and Berbeć, 1997). 
Interestingly, the impact of mechanisation is strongly under-explored in steep-slope cultivation systems, such as agricultural terraces. Nonetheless, these landscapes are known to be erosion-prone (Tarolli et al., 2014), vineyards more than any other cultivation system, with erosion rates similar to bare soil (Cerdan et al,. 2010; Kosmas et al., 1997; Maetens et al., 2012). Few studies were previously carried out in Catalonian vineyard terraces (Ramos, 2016; Ramos et al., 2007, 2015), where traditional terrace systems have been widely transformed to allow the use of machinery in recent decades. According to different simulations, the traditional terraces showed 45\% (Ramos, 2016) to 57\% (Ramos et al., 2015) lower soil loss rates than the mechanised terraces, due to altered design and loss of soil and water conservation techniques related to the latter. Others have reported the potentially disturbing effect of tillage operations in these type of agricultural systems (Lieskovský and Kenderessy, 2012; e.g. Martínez-Casasnovas and Ramos, 2009). The effect of tractor traffic on soil compaction, hydraulic conductivity, runoff and soil erosion has been sparsely studied in vineyards in Italy (Capello et al., 2017; Ferrero et al., 2005), Spain (Arnáez et al., 2012), France (Polge de Combret-Champart et al., 2013) and Croatia (Bogunovic et al., 2017). The degree of traffic affects soil texture and permeability, and can therefore limit infiltration rates particularly after harvest periods (which corresponds to the wet fall period in many Mediterranean zones). Despite the significant impact of mechanisation on the most erosion-prone landscape type, the number of studies is thus limited. Moreover, the existing studies focus almost entirely on soil management effects within a single field or plot. An integrated and representative study of the mechanisation impact on soil and terrain morphology, while analysing multiple vineyards in a larger zone and thus considering a heterogeneous context, is still missing.

In the Mediterranean basin, Italy is a country with high rates of soil erosion (Panagos et al., 2015a). One of the major contributing factors is the topography: about $75 \%$ of the country is covered by mountains and hills, grouped in the Alps and the Apennines mountain ranges (Canuti et al., 2004). This is amplified by hillslope land use, such as the widespread vineyard terrace levelling (Bazzoffi et al., 2006). Another major factor is the Italian climate, which is characterised by high rainfall aggressiveness (Poesen and Hooke 1997; Panagos et al., 2015a; Sofia et al., 2017). Furthermore, the integration of machinery in viticulture production since recent decades is potentially aggravating these erosion-prone conditions. It is therefore of crucial importance to quantitatively estimate the additional soil loss due to vineyard mechanisation. In this study, the Revised Universal Soil Loss Equation (RUSLE) is applied in a wine-production zone in north-eastern Italy, which is characterised by strong rainfall erosivity and steep slope cultivation. Special attention is given to the mechanisation effect on soil properties (i.e. compaction impact on soil erodibility) and terrace designs (i.e. geomorphologic impact on slope lengths and steepness), based on multiple study sites with various degrees of mechanisation. By analysing 24 dispersed vineyards, the natural variability of this zone in terms of climate and the anthropogenic variability of terrace morphology, infrastructure and management is represented. Results are then compared using statistical tests to investigate the 
Pijl et al.

significance of the impact of steep-slope vineyard mechanisation on estimated soil loss.

\section{The study area}

The studied vineyards are situated in the Veneto region, northern Italy (Fig. 1).

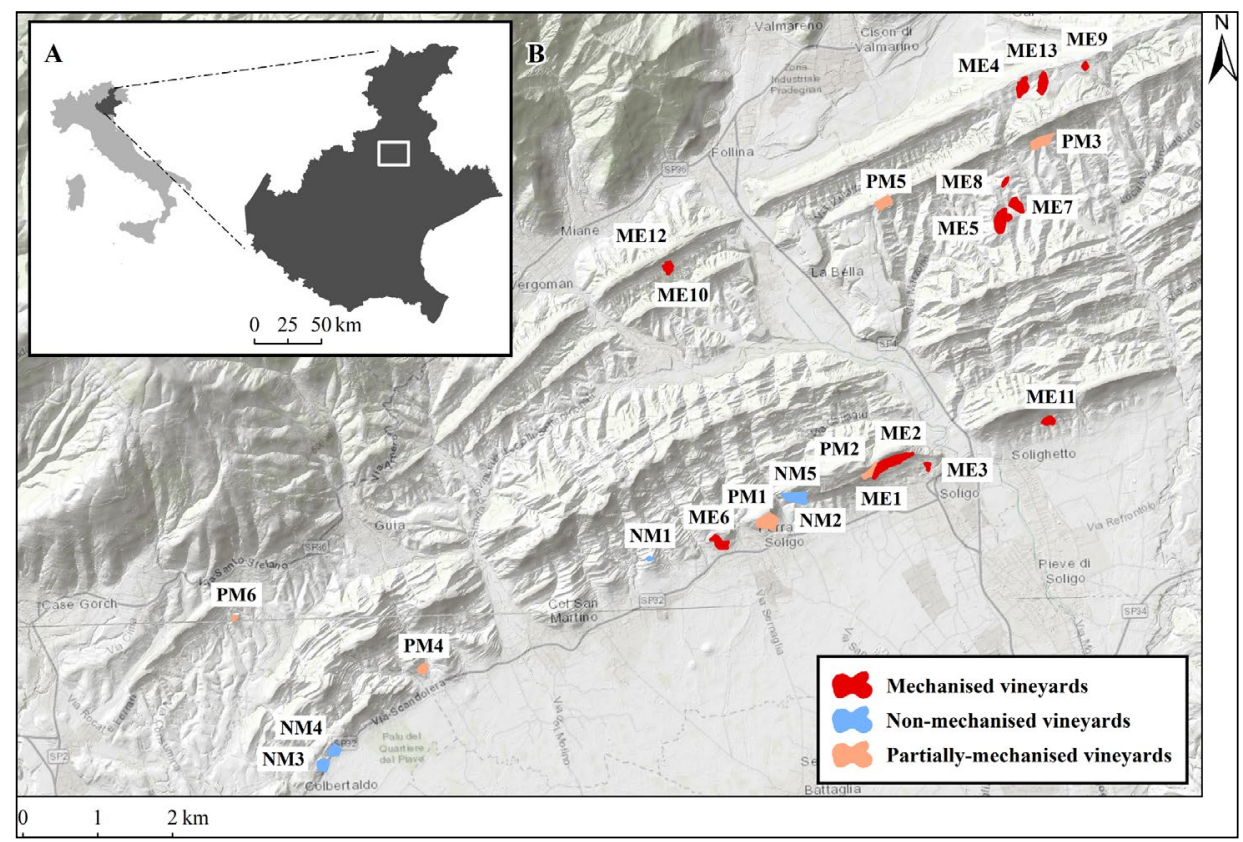

Figure 1. Geographical overview of the study area: $(A)$ its location in Italy and Veneto Region (white bounding box); and (B) the 24 vineyards analysed in this study.

The wine-production zone is characterised by its hilly relief with an average slope value of $14.6 \pm 13.3^{\circ}$ (topographic analysis was based on LiDAR data by Blanos et al., 2009). The presence of steep hillsides and terrace walls are indicated by $99^{\text {th }}$ percentile and maximum slope gradients of $53.0^{\circ}$ and $89.4^{\circ}$, respectively. Elevations range between $34 \mathrm{~m}$ a.s.l. in the valleys and $613 \mathrm{~m}$ a.s.l. on the hilltops. Annual rainfall is relatively high with $1428 \mathrm{~mm}$ (20-y average from 3 stations; ARPAV, 2015) and has a strong inter-annual variation with a standard deviation of $381 \mathrm{~mm}$. Typically vines are cultivated on terraces constructed on steep hillslopes with southern or eastern orientation, while northern faces are dominated by forests, creating a homogenous and particular landscape (Regione Veneto, 2016). Traditionally, terraces are constructed using earth banks (Italian: "ciglionamento", Fig. 2A) which is still characteristic for this area, although cultivation perpendicular to the contour ("a rittochino") has been adopted for the facilitation of machinery use (Agnoletti et al., 2011). Mechanisation has spread discontinuously throughout this zone due to the heterogeneous terrain, making it an interesting area for comparison. 

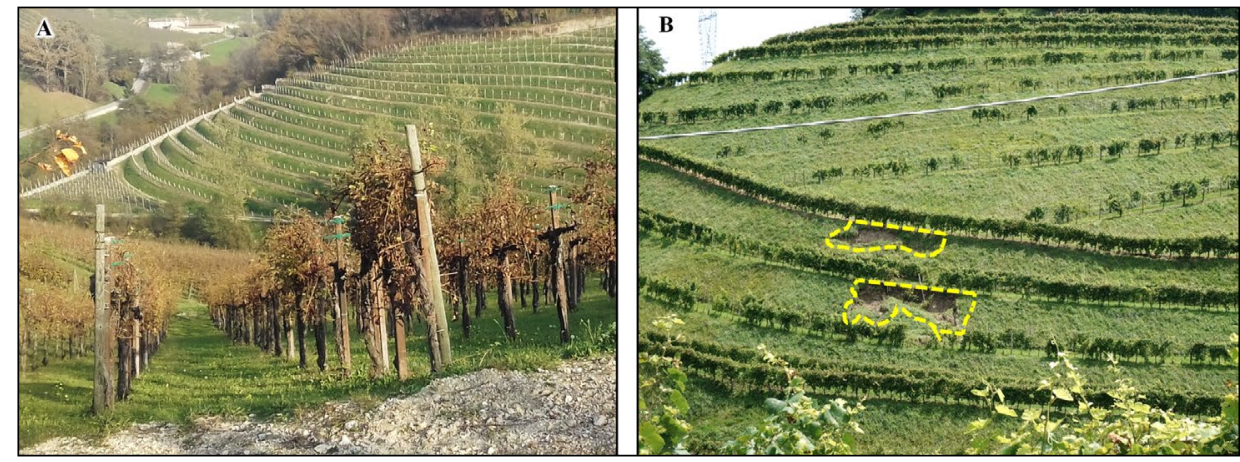

Figure 2. Typical terraced vineyard landscape found in the study area. (A) Example of mechanised vineyards: vertical cultivation in the foreground ("a ritocchino"), and horizontal earth banks in the background ("ciglionamento"). Mostly the gentle slopes are transformed for mechanisation while the steeper slopes remain manually cultivated. (B) Example of shallow landslides on terrace banks (yellow), driven by water flow accumulation and release from tractor paths in the vineyard. Graphics are original work by the authors.

As a consequence of the steep cultivated slopes and high rainfall rates (among other factors), this zone is prone to soil erosion (Fig. 2B). An estimation by the regional environmental protection agency (ARPAV, 2008) showed that all 15 municipalities included in the wine-production zone contain areas with "soil erosion rates" (i.e. $>6 \mathrm{t} \mathrm{ha}^{-1} \mathrm{y}^{-1}$ ).

These high erosion rates pose a threat to the human safety, cultural heritage and economic productivity. Among the wine-production zones in Italy, this region is the most productive by far, with over 3.64 million hectolitres of wine per year which is steadily growing (ISTAT, 2016). Its economic value is furthermore established by a growing popularity among international tourists (Boatto et al., 2013). The unique aesthetic character of this zone should be preserved as cultural heritage (Regione Veneto, 2016), and as a tourist destination (Boatto et al., 2006).

\subsection{Studied vineyards}

A total of 24 vineyards were selected in order to represent a diverse set of conditions and hence to minimise biased results from field-specific circumstances. Predominant soil type in these sites is fine-granular clay loam (ARPAV, 2011; details found in Section 3.2). All sites consist of similar vineyard cultivation systems with inter-row grass cover, and a variable degree of mechanisation on field patches. On site-scale, 13 vineyards fully consist of mechanised field, 5 vineyards have no mechanised fields (only paths and roads), and 6 vineyards contain both field patches (Table 1). The average vineyard size is 1.4 ha (with strong variation between fields), while the total coverage of mechanised and non-mechanised field patches is comparable in size (resp. 22.4 and 15.4 ha). Slope values found in the 24 study sites are slightly higher than the surrounding zone, with an average of $25.0 \pm 9.9^{\circ}$, making these potential erosion hot-spots. 
Pijl et al.

Table 1. Spatial characteristics of the 24 studied vineyards, with respective acronyms for fully-mechanised vineyards (ME\#), non-mechanised vineyards (NM\#) and partly-mechanised vineyards (PM\#).

\begin{tabular}{|c|c|c|c|c|}
\hline FIELD & $\begin{array}{c}\text { MECHANISED } \\
\text { FIELDS } \\
\text { PRESENT } \\
\end{array}$ & $\begin{array}{c}\text { TOTAL } \\
\text { SURFACE } \\
\text { AREA (ha) } \\
\end{array}$ & $\begin{array}{l}\text { AVERAGE } \\
\text { SLOPE }\left(^{\circ}\right)\end{array}$ & $\begin{array}{c}\text { COVERAGE } \\
\text { BY PATHS AND } \\
\text { ROADS }(\%) \\
\end{array}$ \\
\hline ME1 & yes & 1.6 & 36.1 & 3.4 \\
\hline ME2 & yes & 2.3 & 35.6 & 0.5 \\
\hline ME3 & yes & 0.3 & 17.9 & 0.0 \\
\hline ME4 & yes & 2.1 & 14.9 & 7.6 \\
\hline ME5 & yes & 3.7 & 19.6 & 5.2 \\
\hline ME6 & yes & 1.8 & 20.2 & 6.8 \\
\hline ME7 & yes & 1.8 & 19.5 & 8.0 \\
\hline ME8 & yes & 0.3 & 23.6 & 3.0 \\
\hline ME9 & yes & 0.4 & 13.0 & 6.9 \\
\hline ME10 & yes & 0.3 & 23.0 & 1.1 \\
\hline ME11 & yes & 1.1 & 22.8 & 2.3 \\
\hline ME12 & yes & 0.8 & 21.7 & 5.2 \\
\hline ME13 & yes & 2.1 & 15.2 & 13.0 \\
\hline NM1 & no & 0.1 & 29.3 & 4.3 \\
\hline NM2 & no & 0.9 & 36.8 & 16.3 \\
\hline NM3 & no & 1.3 & 24.0 & 8.3 \\
\hline NM4 & no & 0.9 & 33.4 & 15.4 \\
\hline NM5 & no & 1.8 & 32.1 & 11.3 \\
\hline PM1 & partly & 3.6 & 28.7 & 9.0 \\
\hline PM2 & partly & 1.1 & 31.8 & 16.2 \\
\hline PM3 & partly & 2.5 & 23.9 & 7.8 \\
\hline PM4 & partly & 0.9 & 24.4 & 9.8 \\
\hline PM5 & partly & 1.9 & 26.9 & 3.7 \\
\hline PM6 & partly & 0.2 & 25.1 & 7.7 \\
\hline Average & - & 1.4 & 25.0 & 7.2 \\
\hline
\end{tabular}

\section{Methods}

In this study, the Revised Universal Soil Loss Equation (RUSLE) has been applied to the 24 study sites with mixed mechanised and non-mechanised practices. Data preparation and final computations were carried out in a GIS environment, using basic operations such as raster algebra (details on specific approaches and metadata is given in Section 3.2).

\subsection{Revised Universal Soil Loss Equation (RUSLE) and mechanisation effect}

A commonly used tool for soil erosion assessment accounting for geologic, climatic and management-based factors (including mechanisation), is the Revised Universal Soil Loss Equation (RUSLE; Renard et al., 1997). This empirical method was developed 
by the U.S. Department of Agriculture (USDA) and has become the most frequently used tool for estimating soil erosion (Karydas et al., 2014). It superseded the Universal Soil Loss Equation (USLE; Wischmeier and Smith, 1978) for better suitability in global applications (e.g. by an improved effect of slope). The equation consists of several factors of equal weight, typically having a spatial distribution:

$$
A=R \cdot K \cdot L \cdot S \cdot C \cdot P
$$

where $A$ is estimated average annual soil loss $\left(\mathrm{t} \mathrm{ha}^{-1} \mathrm{y}^{-1}\right) ; R$ is the rainfall-runoff erosivity factor ( $\left.\mathrm{MJ} \mathrm{mm} \mathrm{ha}{ }^{-1} \mathrm{~h}^{-1} \mathrm{y}^{-1}\right) ; K$ is the soil erodibility factor ( $\mathrm{t} \mathrm{ha} \mathrm{h} \mathrm{ha-1} \mathrm{MJ}^{-1} \mathrm{~mm}^{-1}$ ); $L$ is the slope length factor, commonly combined in calculation with the slope steepness factor $S$ (dimensionless); $C$ is the cover-management factor (dimensionless); and $P$ is the support practice factor (dimensionless). For a complete description of the equation and for more background on the factors, the authors refer to Renard et al. (1997).

The impact of vineyard mechanisation is conceptualised in this study based on two RUSLE factors, following two hypotheses based on general scientific findings and consensus (as discussed in Section 1):

(i) Soil erodibility $K$ is expected to increase due to machinery-induced compaction, which reduces soil permeability and infiltration rates, thus increasing surface run-off and erosion rates.

(ii) Slope length and steepness $L S$ are expected to increase due to the presence of broader terraces to allow machinery traffic, and related steeper and longer risers (terrace walls).

\subsection{Data sources}

Several data sources were used in this study to compute the RUSLE factors, combining both primary and secondary sources. The online European Soil Data Centre (ESDAC; European Commission, 2012) provided the following open-source datasets of all RUSLE factors on European scale. Of these, only the maps of rainfall erosivity $R$ and support practices $P$ were directly used for soil loss estimations in this study (in which $P$ is constant across study areas), while other European maps served merely a secondary purpose. A rainfall erosivity $R$ map (500-m grid) was produced by Panagos et al., (2015b) from 5-40 years of rainfall measurements from 1541 precipitation stations with 5 to $60 \mathrm{~min}$ of temporal resolution. A soil erodibility $K$ map (500-m grid) was interpolated by Panagos et al. (2014) using spatial covariates, based on 20.000 soil samples by the Land Use/Cover Area Survey (Toth et al., 2013). A slope length and steepness $L S$ map was created from the space-borne EU-DEM (25-m grid) by Panagos et al. (2015c), following the Desmet and Govers (1996) equation implemented in System for Automated Geoscientific Analyses (SAGA) GIS software. A cover-management $C$ map (100-m grid) was derived by Panagos et al. (2015d) from CORINE land cover data, remote sensing data of vegetation density and statistical analysis of cultivation practices. Finally, a map of support practices $P(100-$ m grid) was generated by Panagos et al. (2015e) based on European regulations of contour farming, and the presence of grass margins and stone walls in the LUCAS dataset. 
In this study, ESDAC $R$ and $P$ maps were used directly without modification, while the remaining maps were to some extent modified or recreated by the authors. The covermanagement $C$ value was set uniformly to 0.253 across sites, based on the all-site average of ESDAC values, in order to avoid raster boundary artefacts in further computations. The use of low-resolution layers is justified by the homogeneity of terrace practice $P$ and cover management $C$, and the relatively large scale of rainfall drivers $R$ compared to field-scale $K$ and $L S$. Given the hypothesised impact of mechanisation on factors $K$ and $L S$ (see Section 21), a higher resolution than the ESDAC maps was required to capture related processes, which was achieved by downscaling by the authors. Thus, the ESDAC maps of $K$ and $L S$ were merely used as a reference after this process, as well as ESDAC estimates of soil loss.

A high-resolution $L S$ map was generated for this study based on a LiDAR DTM with 1-m resolution, provided by the Province of Treviso (Blanos et al., 2009). The topographic data originated from a joint mission between the Province and the National Institute of Oceanography and Experimental Geophysics (OGS), which was called "Progetto Geo7". The survey was carried out in 2008 and 2009 using airborne laser scanning using the ALTM GEMINI system, recording a minimum of 2 points per square meter. The surface reconstruction was validated with over 500 GPS ground measurements, resulting in an average vertical error of a few centimetres. Computation of the $L S$ factor in the present study was carried out using SAGA GIS software, following the Desmet and Govers (1996) method for suitable capturing of complex landscape features (Panagos et al. 2015c).

A high-resolution $K$ map for this study was generated following the standard USLE nomograph method by Wischmeier and Smith (1978) based on soil texture, organic content, structure and permeability. The former three characteristics were determined through spatial analysis based on a regional open-source soil database (ARPAV, 2011), showing fine granular soils of type clay loam (USDA classification) in the study sites. In the USLE nomograph derivation, the following values from the soil database were pursued: $35 \%$ of silt and very fine sand; $30 \%$ of sand; $2 \%$ of organic matter; and soil structure class 2 ("fine granular"). Spatial heterogeneity in $K$ values was introduced by assigning different permeability classes to four distinct field patches identified by field inspection. A distinction was made of: (i) non-mechanised field patches, (ii) mechanised field patches (iii), mechanised paths, and (iv) mechanised roads (the latter characterised by the presence of gravel). Given that no intra-field soil characteristics were available for this extensive area, permeability values were assumed to range between nomograph classes 1 and 6; as "rapid permeability" for non-mechanised fields (class 1), "slow to moderate permeability" for mechanised fields (class 4), "slow permeability" for paths (class 5) and "very slow permeability" for roads (class 6). The uncertainty related to this step was minimised by ensuring that derived $K$ values did not exceed the range of calculated values by Panagos et al. (2014). After conversion into SI units (Foster et al., $1981), K$ values for the four groups were respectively $0.016,0.025,0.029$ and $0.032 \mathrm{t}$ ha $\mathrm{h} \mathrm{ha}^{-1} \mathrm{MJ}^{-1} \mathrm{~mm}^{-1}$, which was in strong agreement with the ESDAC values specifically at these sites of (see Section 4.1). 


\subsection{Quantitative comparison}

A quantification of RUSLE soil loss estimates was based on the various field patches (i.e. non-mechanised fields, mechanised fields, paths, roads) rather than complete vineyards, by extracting the raster values inside the polygons belonging to each sample group. A first comparison was based on a boxplot showing the spread of soil loss rates per group and allowing a relative confrontation of group values. Groups were analysed individually (i.e. 4 group datasets) and in a non-mechanisation vs. mechanisation comparison (i.e. 2 datasets; non-mechanised vs. the remaining 3 mechanised groups combined). The latter was considered a representative comparison for the fact that compacted paths or roads are inherent to the mechanisation system.

In addition, the statistical significance of the difference among groups was tested using the one-way ANOVA on ranks by Kruskal and Wallis (1952) and a 95\% confidence interval $(\alpha=0.05)$. The non-parametric method was suitable for the non-normally distributed data samples with unequal lengths (unlike the normal one-way ANOVA). It is similar to the $U$ test by Mann and Whitney (1947), except that it allows comparison of more than two sample groups. The null-hypothesis is that the samples originate from the same distribution (i.e. they have equal medians), which is rejected if at least two of the confronted groups have unequal medians. In this case, the test was repeated with two groups in order to identify where the differences lie.

$L S$ values were also quantitatively compared in 4 groups, in order to distinguish the relative contributions to estimated soil loss by terrain alterations (hypothesis II) and soil alterations (hypothesis I). By way of normalising $L S$ values, the relative impact on estimated soil loss could be understood as well. For that, it was assumed that the linear contribution of RUSLE factors make group average soil loss rates linearly dependent on group averages of $L S$. This is a purely theoretical analysis to identify the relative impacts, and is not presented as a realistic scenario nor as main finding.

\section{Results}

An overview of each RUSLE factor and related values, units, scales and sources is given in Table 2, and is further discussed in the following sections.

Table 2. RUSLE factors and their values, scales and sources, as used in this study.

\begin{tabular}{|r|c|c|l|l|}
\hline & VALUE & UNITS & $\begin{array}{c}\text { SCALE (RESOLU- } \\
\text { TION) }\end{array}$ & \multicolumn{1}{|c|}{ SOURCE } \\
\hline $\mathbf{K}$ & $0.016-0.032$ & $\mathrm{t} \mathrm{ha} \mathrm{h} \mathrm{ha}^{-1} \mathrm{MJ}^{-1} \mathrm{~mm}^{-1}$ & field-scale (vector) & $\begin{array}{l}\text { standard nomograph derivation (Wis- } \\
\text { chmeier and Smith, 1978) supported by } \\
\text { field inspection }\end{array}$ \\
\hline $\mathbf{L S}$ & $0-37$ & - & field-scale (1-m grid) & LiDAR-based DTM \\
\hline $\mathbf{R}$ & $1858-2528$ & $\mathrm{MJ} \mathrm{mm} \mathrm{ha}^{-1} \mathrm{~h}^{-1} \mathrm{y}^{-1}$ & Europe (500-m grid) & (Panagos et al., 2015b) \\
\hline $\mathbf{C}$ & 0.253 & - & Europe (100-m grid) & (Panagos et al., 2015d, modified) \\
\hline $\mathbf{P}$ & 0.97 & - & Europe (100-m grid) & (Panagos et al., 2015e) \\
\hline $\mathbf{A}$ & $7.5-555.3$ & $\mathrm{t} \mathrm{ha}^{-1} \mathrm{y}^{-1}$ & field-scale (1-m grid) & this study \\
\hline
\end{tabular}


Pijl et al.

\subsection{Soil erodibility $(K)$}

The spatial distribution of soil erodibility $K$ is displayed in Figure 3. Values range

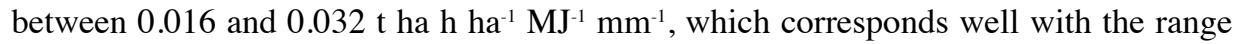
found by Panagos et al. (2014) specifically at these sites $\left(0.015-0.049 \mathrm{t} \mathrm{ha} \mathrm{h} \mathrm{ha}^{-1} \mathrm{MJ}^{-1}\right.$ $\mathrm{mm}^{-1}$ ). Clearly visible in the maps (Fig. 3) are the paths and roads, which are distinguished by their high $K$ values representing the higher degree of traffic. The road patterns are clearly diverse, emphasising the importance of a representative group (i.e. no. of study sites) to minimise stochastic effects in the estimation of soil loss. Bright-yellow polygons depict the non-mechanised field patches $(15.7 \mathrm{ha})$ and orange polygons the mechanised field patches (22.4 ha).

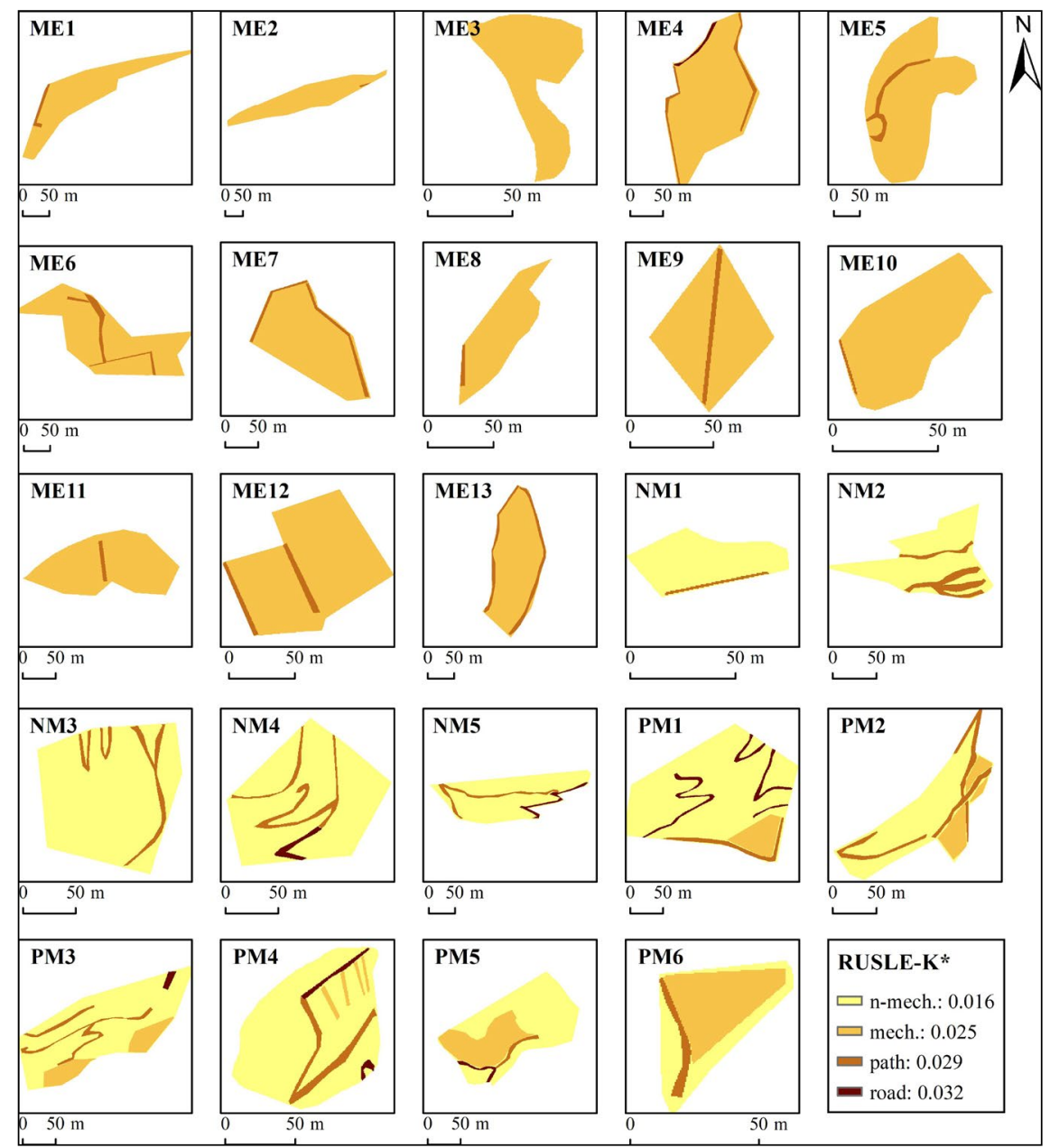

Figure 3. RUSLE soil erodibility factor $K\left(* t\right.$ ha $\left.h \mathrm{ha}^{-1} \mathrm{MJ}^{-1} \mathrm{~mm}^{-1}\right)$ of non-mechanised and mechanised fields patches, paths and roads across the 24 study sites. The spatial distribution is based on field observations by the authors. 


\subsection{Slope length and steepness $(L S)$}

The combined slope length and steepness factors $L S$ are displayed in Figure 4. The 1-m resolution allows a suitable representation of the terrace benches (yellow, low $L S$ ) and walls (orange-red, high $L S$ ) that are present in most of the 24 vineyards. Paths and roads are also easily recognised, which have a respective average $L S$ value of $4.3( \pm 2.4)$ and 5.0 $( \pm 2.6)$. Strikingly, non-mechanised field patches $(6.2 \pm 0.9)$ have a significantly higher $L S$ factor than mechanised field patches by $25 \%(p=0.0142)$. This contrasts the hypothesis of this study that the introduction of machinery requires wider terraces, therefore steeper and longer risers. It is likely that mechanised fields have lower $L S$ values because gentle slopes are firstly (or solely) mechanised as they are the easiest to transform, while mechanisation hardly expands uphill onto the steeper slopes. Apparently, the latter (lower location steepness) outweighs the first (higher riser steepness), considering that average $L S$ values are $25 \%$ higher for non-mechanised vineyards than for mechanised ones (Fig. 5A).

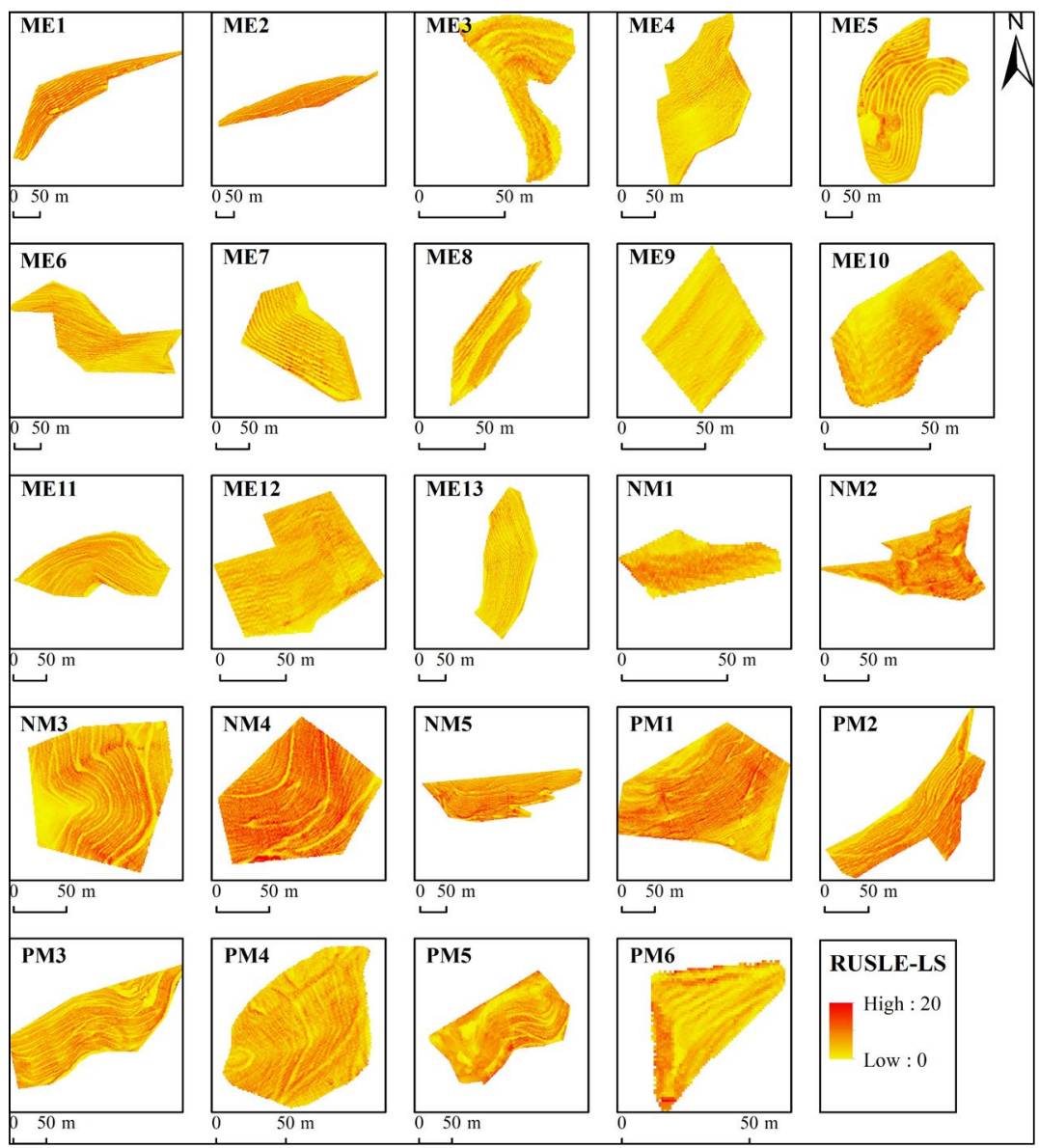

Figure 4. RUSLE slope length and steepness factors LS (-) of the 24 study sites, derived from a LiDAR-based DTM of 1-m resolution. 


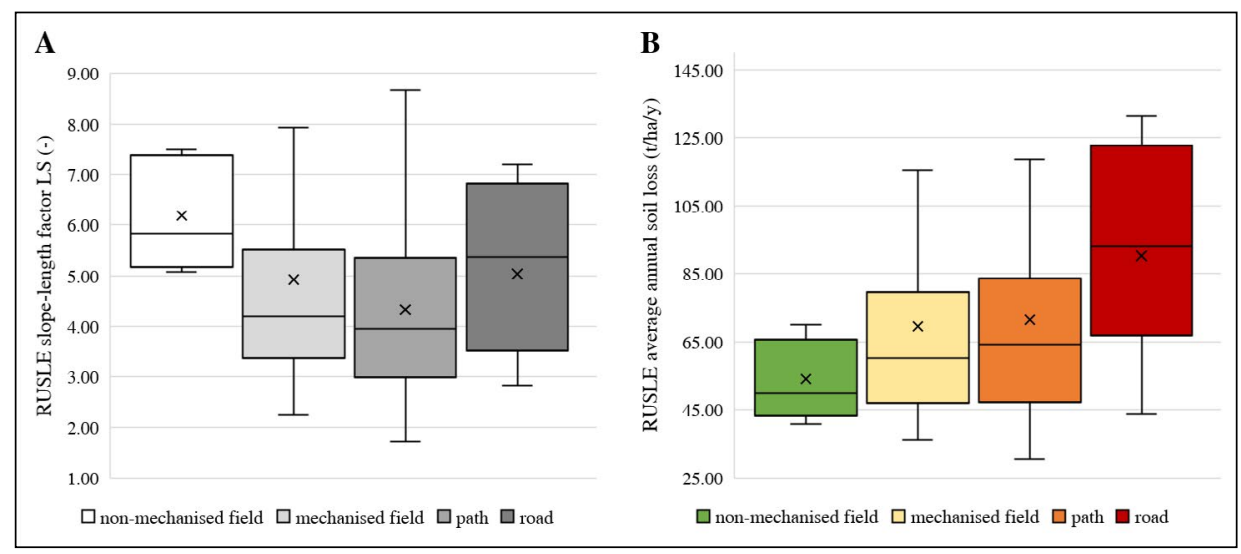

Figure 5. (A) RUSLE slope length and steepness factor LS (-) for the four distinguished groups. (B) RUSLE average annual soil loss estimates $\left(t h \mathrm{~h}^{-1} \mathrm{y}^{-1}\right)$ of the four distinguished groups. Nonmechanised fields show the lowest variance and average rates of soil loss, while mechanised fields, paths and roads have wider ranges and higher average rates.

\subsection{Rainfall erosivity $(R)$, cover-management $(C)$ and support practice $(P)$}

Values of rainfall erosivity $R$, cover-management $C$ and support practice $P$ factors extracted in the study sites are depicted in Table 2, of which the latter two are constants of 0.253 and 0.97 , respectively. Rainfall erosivity $R$ varies roughly between 584-6228 MJ $\mathrm{mm} \mathrm{ha} \mathrm{A}^{-1} \mathrm{~h}^{-1} \mathrm{y}^{-1}$ in the Veneto region, hence representing nearly the full range of minimum and maximum values of the whole country. The spatial distribution of $R$ values follows the processes of climate and geographical features in this zone. Highest values are found along the eastern border of the region (towards the Friuli-Venezia Giulia region), where humid airflow from the Adriatic Sea moves northwards over the lowlands and meets the foothills of the Alps and causes convection. The 24 study sites are slightly heterogeneous in terms of $R$-values, ranging between 1858 and $2528 \mathrm{MJ} \mathrm{mm} \mathrm{ha}^{-1} \mathrm{~h}^{-1} \mathrm{y}^{-1}$ roughly from west to east (see Supplementary Material A).

\subsection{RUSLE estimated annual soil loss}

Estimates of soil loss rates by the Revised Universal Soil Loss Equation across the 24 vineyards are shown in Fig. 6. Values range between 7.5 and 555.3 $\mathrm{t} \mathrm{ha}^{-1} \mathrm{y}^{-1}$, with relatively higher soil losses widespread throughout sites ME1, ME2, NM2, PM1, and PM2. The impact of roads and paths on estimated soil loss can be clearly recognised in sites PM1, PM2, NM2 and NM4. Partly mechanised vineyards illustrate the impact of the $K$ factors of different patches on estimated soil loss, e.g. in PM2, PM3 and PM5. High soil loss estimates in ME5 (red parts in upper segment) correspond in location to the field-observed terrace damages displayed in Fig. 2B, and is likely the result of runoff accumulation and release by the compacted path in this site (compare Fig. 3, ME5). Soil loss rates per group are plotted in Fig. 5B 
(i.e. non-mechanised field patches, mechanised field patches, paths and roads). Nonmechanised fields show the lowest average soil loss rates $\left(53.9 \mathrm{t} \mathrm{ha}^{-1} \mathrm{y}^{-1}\right)$, compared to mechanised fields $(+29 \%)$, paths $(+32 \%)$, and roads $(+67 \%)$. The former also represents the lowest standard deviation $\left(\sigma n-m e c h=10.6 \mathrm{t} \mathrm{ha}^{-1} \mathrm{y}^{-1}\right)$ in respect to the other groups $\left(\sigma_{\text {mech. }}=18.5 ; \sigma_{\text {path }}=20.5\right.$; and $\left.\sigma_{\text {road }}=28.5 \mathrm{t} \mathrm{ha}^{-1} \mathrm{y}^{-1}\right)$, indicating the relative consistency of the values in the non-mechanised group. A comparison of the latter three mechanised groups combined, shows a $37 \%$ higher average soil loss than non-mechanised fields, with $73.6 \pm 18.5 \mathrm{tha}^{-1} \mathrm{y}^{-1}$.

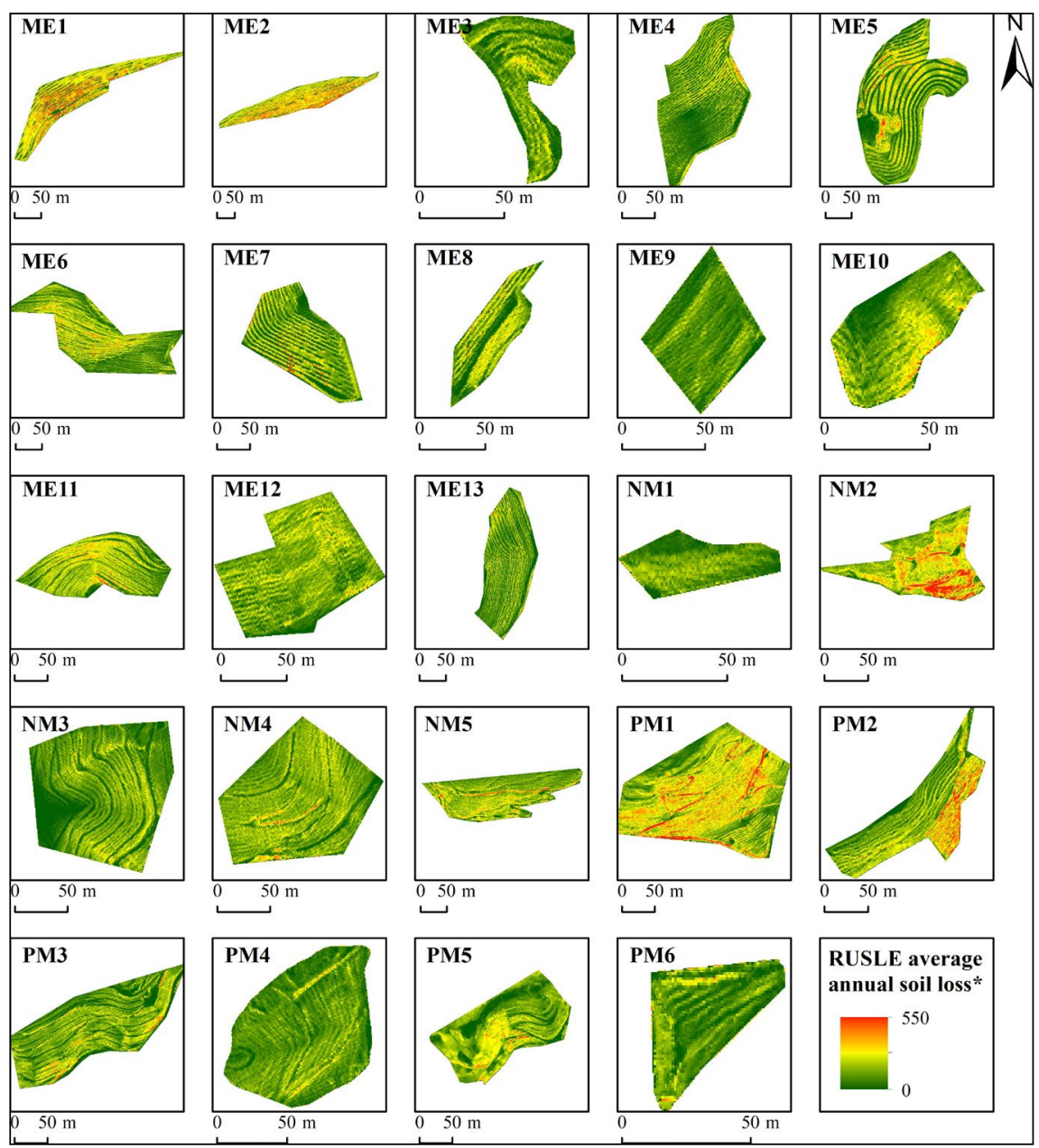

Figure 6. RUSLE average annual soil loss estimates $\left(t h a^{-1} y^{-1}\right)$ of the 24 study sites. Erosion varies strongly within the plots and among the different plots, here mostly due to variations in soil erodibility $K$ (due to the use of machinery), and in slope length and steepness $L S$. 


\subsection{Significance testing}

Statistical comparison using the Kruskal-Wallis test showed that the four sample groups of soil loss rates (Fig. 5B) are significantly different from each other with a $95 \%$ confidence interval $(p=0.0299)$. In addition, the three mechanised groups combined show significantly higher rates $(p=0.0374)$. However, this is not the case for a one-toone comparison between non-mechanised field patches and mechanised field patches $(p=0.1492)$. The direct mechanisation impact is underestimated in this comparison because naturally milder slopes are likely favoured in the spread of mechanisation (see Fig. 5A and Section 4.2 above). In the theoretical case where the average variation in $L S$ values was normalised, annual soil loss rates from mechanised fields would be $61 \%$ higher than non-mechanised fields, although mechanisation may not be realistic at such slopes. Most importantly, the status quo is that the spread of mechanisation is mostly limited to the gentler hillsides, and is unlikely to expand much further upslope, making the non-normalised situation the most relevant scenario to be considered.

\section{Discussion and recommendations}

\subsection{Aggravating potential of mechanisation in an erosion-prone landscape}

The magnitude of RUSLE soil loss estimates of this study is relatively high. The presented soil loss rates of $64.8 \pm 42.6 \mathrm{tha}^{-1} \mathrm{y}^{-1}$ are greatly above the tolerable soil loss rate of 1-2 $\mathrm{t} \mathrm{ha}^{-1} \mathrm{y}^{-1}$ (Verheijen et al., 2009; based on soil formation rate) or above European and Italian averages of respectively 2.2 and $8.4 \mathrm{t} \mathrm{ha}^{-1} \mathrm{y}^{-1}$ (Panagos et al., 2015a). Hillslope vineyards are generally known to be responsible for above-average rates with an average of $17.9 \mathrm{t} \mathrm{ha}^{-1} \mathrm{y}^{-1}$ (Maetens et al., 2012), but several USLE studies show that rates in Spanish and Greek terraces are often below $3 \mathrm{t} \mathrm{ha}^{-1} \mathrm{y}^{-1}$ (Arnáez et al., 2015). Similar studies on Italian terraced landscapes, however, confirm high soil loss rates in Piedmont with $20.7 \mathrm{t} \mathrm{ha}^{-1} \mathrm{y}^{-1}$ (Biddoccu et al., 2016), in Calabria with 7.8-56.5 t ha-1 $\mathrm{y}^{-1}$ (Bazzoffi et al., 2006), and in Campania with $53 \mathrm{t} \mathrm{ha}^{-1} \mathrm{y}^{-1}$ (Fagnano et al., 2012). The validity of the presented findings is supported by other studies, e.g. European estimates extracted specifically at these sites (Panagos et al., 2015a), both in terms of average and standard deviation $\left(51.3 \pm 60.8 \mathrm{t} \mathrm{ha}^{-1} \mathrm{y}^{-1}\right)$. The higher average soil loss found here can be attributed to the higher resolution of $L S$ input, which is known to be produce higher soil loss estimates (Molnár and Julien, 1998). Also Rodrigo-Comino (2018) concluded from a meta-analysis of vineyard erosion that Italy has the highest average soil loss, with reported rates of $\sim 40 \mathrm{t} \mathrm{ha}^{-1} \mathrm{y}^{-1}$ and a $75^{\text {th }}$ percentile of $\sim 85 \mathrm{tha}^{-1} \mathrm{y}^{-1}$. Literature thus seems to indicate that a diverse set of factors constitute an erosion-prone situation in Italian vineyards. Therefore, mechanisation practices should be carefully planned and evaluated for their additional pressure on soil conservation. In present-day, a complete avoidance of machinery use in vineyards is not feasible anymore due to the economic competition with mechanised viticulture. In fact, most remaining manuallycultivated vineyards across the Mediterranean are found on the steepest slopes (Biddoccu et al., 2018; Fernandes et al., 2017; Komac and Zorn, 2008; Savo et al., 2014) and their abandonment and consequent land degradation are well-documented (Arnáez et 
al., 2015; e.g. García-Ruiz and Lana-Renault, 2011; Tarolli et al., 2014). The suitability and optimal design of mechanised terraces is highly dependent on local conditions (e.g. climate and soil) and should ideally be based on maximum tolerable soil loss (as e.g. done by Ramos and Porta, 1997).

\subsection{Recommendations for steep-slope agricultural practices}

Different mitigation strategies exist to minimise mechanisation-induced erosion. Generally, the use of a mid-row ripper (Fig. 7B and 7C) can aerate and increase the soil porosity. The problem of soil compaction can be addressed by the use of a ridge ploughing under the wheel tracks (Bangita and Rao, 2012). Another example of a low-impact mechanisation strategy is the simultaneous operations by multifunctional machinery (Longo et al., 2010; Pellenc and Delran, 2000), that minimise the passages in vineyard inter-rows. In addition, farmers should avoid the machine passage with excessive soil moisture, as it may accelerate soil compaction and damage the soil structure (Keller and Lamandé, 2010). Moreover, optimised cover management with different grass species can improve the soil organic matter and reduce the soil compaction (Fig. 7A). Grass cutting and its mixing within the soil can enhance the soil organic carbon, increasing the soil porosity and thus indirectly reducing soil compaction (Steenwerth and Belina, 2008). However, a bare soil should be avoided as much as possible, given that erosion rates decrease exponentially with vegetative cover (Gyssels et al,. 2005).
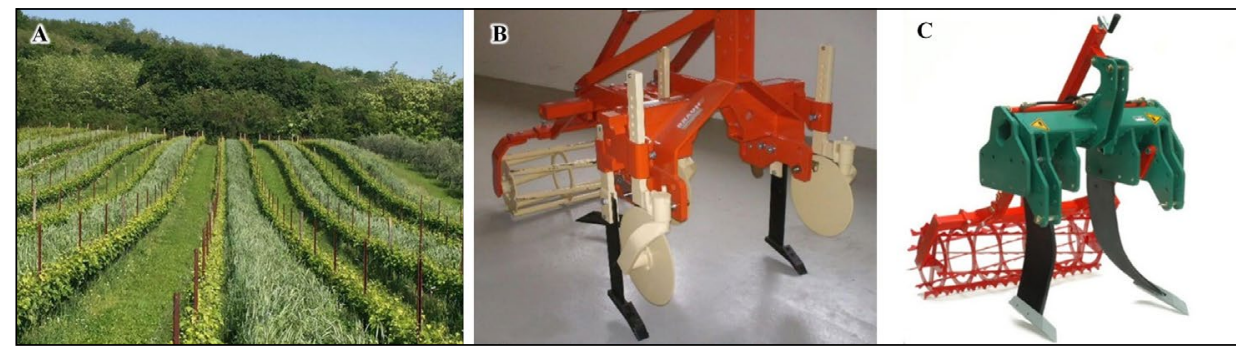

Figure 7. Examples of strategies for soil erosion mitigation: (A) cover crops between rows enhance the organic soil content and indirectly reduce the soil compaction (picture by Filippo Costa); (B-C) the mid-row ripper is an operative machine designed to reduce the soil compaction on the machine tracks (graphics by Andrea Pezzuolo).

\subsection{Recommendations and limitations of the research}

Soil loss estimates by RUSLE are subject to several uncertainties, for instance from the derivation of its factors. In this study, $K$ factor was determined using the default nomograph method (Wischmeier and Smith, 1978). This is partly based on known soil properties, and partly on the assumed permeability classes (i.e. ranging from "very slow" to "rapid"). Although this adds a degree of uncertainty to the presented rates, the resulting range is in good agreement with other studies for the study sites (Section 4.1). Furthermore, in this study the $C$ factor does not vary, as grass coverage on vineyard 
inter-rows were found to be homogeneous among all sites. However, vineyards can have variable vegetative cover throughout the year (Biddoccu et al., 2017; Novara et al., 2011). In dry climates, farmers may even maintain a bare soil to avoid any water competition with the vines (Marques et al., 2010). In addition, the $P$ factor may be interesting to study among different types of hillslope vineyards, comparing soil loss under different type of terraces (e.g. dry-stone walls, earth banks) or the absence of terraces (cultivation along or perpendicular to the contour). Finally, changing climatic conditions could be further studied, as many Mediterranean zones are additionally challenged by increasing rainfall erosivity over time (Diodato et al., 2011).

\section{Conclusions}

In the high-steep slope vineyard landscapes, mechanisation is increasing the challenge of soil conservation and sustainable terrace management. The use of machinery often involves a transformation of the traditional terraces and moreover, it induces soil compaction by tractor traffic on vineyard inter-rows and infrastructure. Erosion estimates by the Revised Universal Soil Loss Equation (RUSLE) in 24 vineyards in northern Italy are shown to be $37 \%$ higher in mechanised fields, paths and roads compared to nonmechanised fields $(p=0.0374)$, which is largely the result of reduced soil permeability.

These findings offer an integrated quantification of the effects of machinery use in vineyards, which thus far have been marginally studied across a representative set of vineyards. The aggravating erosion potential of this practice should be acknowledged and minimised in steep-slope agricultural management. In finding solutions, an integrated approach is needed to consider the diverse aspects of a terraced vineyard system, such as conservative soil cover management, optimising the frequency of passage, and mitigating the impact of machinery-adjusted infrastructure on runoff generation and erosion risk.

\section{Acknowledgements}

This study was supported by project ViTE; "Vineyard Terraced landscapes: understanding the Environmental constraints to improve sustainable managements", funded by the Linda Scattolin research program related to the TESAF department of the University of Padova (Italy). The authors would like to thank Klaas M., Andrea P., Filippo C., Edoardo Q., Wenfang C. and Paulina P. for their various support.

\section{References}

Agnoletti, M., Cargnello, G., Gardin, L., Santoro, A., Bazzoffi, P., Sansone, L., Pezza, L., Belfiore, N. 2011. Traditional landscape and rural development: Comparative study in three terraced areas in Northern, Central and Southern Italy to evaluate the efficacy of GAEC Standard 4.4 of Cross Compliance. Italian Journal of Agronomy 6 (1), 121-139. https://doi.org/10.4081/ ija.2011.6.s1.e16.

Arnáez, J., Lana-Renault, N., Lasanta, T., Ruiz-Flaño, P., Castroviejo, J. 2015. Effects of farming terraces on hydrological and geomorphological processes. A Review. Catena 128, 122-134. https://doi.org/10.1016/j.catena.2015.01.021. 
Arnáez, J., Ruiz-Flaño, P., Lasanta, T., Ortigosa, L., Llorente, J.A., Pascual, N., Lana-Renault, N. 2012. Efectos de las rodadas de tractores en la escorrentía y erosión de suelos en laderas cultivadas con viñedos. Cuadernos de Investigación Geográfica 38 (1), 115-130. http://doi. org/10.18172/cig.1278.

ARPAV, 2015. Meteorological Observations during 1994-2015 from Stations, 195, 100, and 189 [Dataset]. Agenzia Regionale per la Prevenzione e Protezione Ambientale del Veneto (ARPAV). http://www.arpa.veneto.it/.

ARPAV, 2008. Valutazione del rischio d'erosione per la regione Veneto. Padova, Italy. Agenzia Regionale per la Prevenzione e Protezione Ambientale del Veneto (ARPAV).

ARPAV, 2011. Regional soil sampling inventory [Dataset]. Agenzia Regionale per la Prevenzione e Protezione Ambientale del Veneto (ARPAV). http://idt.regione.veneto.it/.

Baguette, M., Hance, T. 1997. Carabid beetles and agricultural practices: Influence of soil ploughing. Biological Agriculture and Horticulture 15 (1-4), 185-190. https://doi.org/10.10 80/01448765.1997.9755193.

Bangita, B., Rao, B.K.R. 2012. Impacts of compaction relief treatments on soil physical properties and performance of sugarcane (Saccharum Spp.) under zonal tillage system. Geoderma 189190, 351-356. https://doi.org/10.1016/j.geoderma.2012.07.002.

Batey, T. 2009. Soil compaction and soil management - A review. Soil Use and Management. https://doi.org/10.1111/j.1475-2743.2009.00236.x.

Bazzoffi, P., Abbattista, F., Vanino, S., Pellegrini, S. 2006. Impact of Land Levelling for Vineyard Plantation on Soil Degradation in Italy. Bollettino Della Societa Geologica Italiana, Supplemento 6 (6), 191-199.

Biddoccu, M., Ferraris, S., Opsi, F., Cavallo, E. 2016. Long-term monitoring of soil management effects on runoff and soil erosion in sloping vineyards in Alto Monferrato (North-West Italy). Soil and Tillage Research 155, 176-189. https://doi.org/10.1016/j. still.2015.07.005.

Biddoccu, M., Ferraris, S., Pitacco, A., Cavallo, E. 2017. Temporal variability of soil management effects on soil hydrological properties, runoff and erosion at the field scale in a hillslope vineyard, North-West Italy. Soil and Tillage Research 165, 46-58. https://doi.org/10.1016/j. still.2016.07.017.

Biddoccu, M., Zecca, O., Audisio, C., Godone, F, Barmaz, A., Cavallo, E. 2018. Assessment of long-term soil erosion in a mountain vineyard, Aosta Valley (NW Italy). Land Degradation and Development 29 (3), 617-629. https://doi.org/10.1002/ldr.2657.

Blanos, R., De Cillia, C., Paganini, P., Pavan, A., Pietrapertosa, C., Sterzai, P., Coren, F. 2009. Rilievo LiDAR ed iperspettrale della provincia di Treviso. Technical Report by Istituto Nazionale Di Oceanografia and Geofisica Sperimentale (OGS). Dipartimento Di Geofisica Della Litosfera (GDL) - CARS GROUP (Cartography and Remote Sensing).

Boatto, V., Barisan, L., Montedoro, M. 2006. Domanda enoturistica: L'esempio del Trevigiano. AE: Agricoltura, Alimentazione, Economia, Ecologia 6, 16-17.

Boatto, V., Galletto, L., Barisan, L., Bianchin, F. 2013. The Development of wine tourism in the Conegliano Valdobbiadene Area. Wine Economics and Policy 2 (2), 93-101. https://doi. org/10.1016/j.wep.2013.11.003.

Bogunovic, I., Bilandzija, D., Andabaka, Z., Stupic, D., Rodrigo-Comino, J., Cacic, M., Brezinscak, L., Maletic, E., Pereira, P. 2017. Soil compaction under different management practices in a Croatian Vineyard. Arabian Journal of Geosciences 10, 1-9. https://doi.org/10.1007/s12517017-3105-y.

Canuti, P., Casagli, N., Ermini, L., Fanti, R., Farina, P. 2004. Landslide activity as a geoindicator in Italy: significance and new perspectives from remote sensing. Environmental Geology 45 (7), 907-919. https://doi.org/10.1007/s00254-003-0952-5. 
Pijl et al.

Capello, G., Biddoccu, M., Ferraris, S., Pitacco, A., Cavallo, E. 2017. Year-round variability of field-saturated hydraulic conductivity and runoff in tilled and grassed vineyards. Chemical Engineering Transactions 58, 739-744. https://doi.org/10.3303/CET1758124.

Carcamo, H.A. 1995. Effect of tillage on ground beetles (Coleoptera: Carabidae): A farm-scale study in Central Alberta. Canadian Entomologist 127, 631-639. https://doi.org/10.4039/Ent127631-5.

Cerdan, O., Govers, G., Le Bissonnais, Y., Van Oost, K., Poesen, J., Saby, N., Gobin, A., Vacca, A., Quinton, J., Auerswald, K., Klik, A., Kwaad, F.J.P.M., Raclot, D., Ionita, I., Rejman, J., Rousseva, S., Muxart, T., Roxo, M.J., Dostal, T. 2010. Rates and spatial variations of soil erosion in Europe: a study based on erosion plot data. Geomorphology 122 (1-2), 167-177. https://doi.org/10.1016/j.geomorph.2010.06.011.

Chamberlain, D.E., Fuller, R.J., Bunce, R.G.H., Duckworth, J.C., Shrubb, M. 2000. Changes in the abundance of farmland birds in relation to the timing of agricultural intensication in England and Wales. Journal of Applied Ecology 37, 771-788. https://doi.org/10.1046/j.13652664.2000.00548.x.

Chan, K.Y., Oates, A., Swan, A.D., Hayes, R.C., Dear, B.S., Peoples, M.B. 2006. Agronomic consequences of tractor wheel compaction on a clay soil. Soil and Tillage Research 89 (1), 13-21. https://doi.org/10.1016/j.still.2005.06.007.

Desmet, P., Govers, G. 1996. A GIS procedure for automatically calculating the USLE LS factor on topographically complex landscape units. Journal of Soil and Water Conservation 51 (5), 427-433.

Diodato, N., Bellocchi, G., Romano, N., Chirico, G.B. 2011. How the aggressiveness of rainfalls in the Mediterranean lands is enhanced by climate change, 591-599. https://doi.org/10.1007/ s10584-011-0216-4.

European Commission, 2012. The European Soil Data Centre: A one-stop-shop for soil science. Science for Environmental Policy - DG Environment News Alert Service, February 9, 2012.

Fagnano, M., Diodato, N., Alberico, I., Fiorentino, N. 2012. An overview of soil erosion modelling compatible with RUSLE approach. Rendiconti Lincei 23 (1), 69-80. https://doi.org/10.1007/ s12210-011-0159-8.

Fernandes, J., Bateira, C., Soares, L., Faria, A., Oliveira, A., Hermenegildo, C., Moura, R., Gonçalves, J. 2017. SIMWE model application on susceptibility analysis to bank gully erosion in Alto Douro wine region agricultural eerraces. Catena 153, 39-49. https://doi. org/10.1016/j.catena.2017.01.034.

Ferrero, A., Usowicz, B., Lipiec, J. 2005. Effects of tractor traffic on spatial variability of soil strength and water content in grass covered and cultivated sloping vineyard. Soil and Tillage Research 84 (2), 127-138. https://doi.org/10.1016/j.still.2004.10.003.

Foster, G.R., McCool, D.K., Renard, K.G., Moldenhauer, W.C. 1981. Conversion of the Universal Soil Loss Equation to SI metric units. Journal of Soil and Water Conservation 36 (6), 355359.

García-Ruiz, J.M., Lana-Renault, N. 2011. Hydrological and erosive consequences of farmland abandonment in Europe, with special reference to the Mediterranean region - A review. Agriculture, Ecosystems and Environment 140 (3-4), 317-338. https://doi.org/10.1016/j. agee.2011.01.003.

Gyssels, G., Poesen, J., Bochet, E., Li, Y. 2005. Impact of plant roots on the resistance of soils to erosion by water: A review. Progress in Physical Geography 29 (2), 189-217. https://doi. org/10.1191/0309133305pp443ra.

ISTAT, 2016. I Numeri Del Vino [Dataset]. Istuto Nazionale di Statistica (ISTAT). https://www.istat.it. Karydas, C.G., Panagos, P., Gitas, I.Z. 2014. A classification of water erosion models according to their geospatial characteristics. International Journal of Digital Earth 7 (3), 229-250. https:// doi.org/10.1080/17538947.2012.671380. 
Keller, T., Lamandé, M. 2010. Challenges in the development of analytical soil compaction models. Soil and Tillage Research 111 (1), 54-64. https://doi.org/10.1016/j.still.2010.08.004.

Komac, B., Zorn, M. 2008. Landsliding in Goriška Brda. In: E. Fontanari, D. Patassini (Eds.), Terraced landscapes of the Alps: Projects in progress. Venezia, ALPTER, pp. 23-27.

Kosmas, C., Danalatos, N., Cammeraat, L.H., Chabart, M., Diamantopoulos, J., Farand, R., Gutierrez, L., Jacob, A., Marques, H., Martinez-Fernandez, J., Mizara, A., Moustakas, M., Nicolau, J.M., Oliveros, C., Pinna, G., Puddu, R., Puigdefabregas, J., Roxo, M., Silamo, A., Stamou, G., Tomasi, N., Usai, D., Vacca, A. 1997. The effect of land use on runoff and soil erosion rates under Mediterranean conditions. Catena 29 (1), 45-59. https://doi.org/10.1016/S0341-8162(96)00062-8.

Kruskal, W.H., Wallis, W.A. 1952. Use of ranks in one-criterion variance analysis. Journal of the American Statistical Association 47 (260), 583-621. https://doi.org/10.1080/01621459.1952 .10483441 .

Lieskovský, J, Kenderessy, P. 2012. Modelling the effect of vegetation cover and different tillage practices on soil erosion in vineyards: A case study in Vrable (Slovakia) Using WATEM/ SEDEM. Land Degradation \& Development 25 (3), 288-296. https://doi.org/10.1002/ ldr.2162.

Lipecki, J., Berbeć, S. 1997. Soil management in perennial crops: orchards and hop gardens. Soil and Tillage Research 43 (1-2), 169-184. https://doi.org/10.1016/S0167-1987(97)00039-1.

Longo, D., Pennisi, A., Bonsignore, R., Muscato, G., Schillaci, G. 2010. A multifunctional tracked vehicle able to operate in vineyards using gps and laser range-finder technology. In: International Conference Ragusa SHWA2010 Work Safety and Risk Prevention in AgroFood and Forest Systems. Ragusa, Italy, pp. 487-492.

Maetens, W., Vanmaercke, M., Poesen, J., Jankauskas, B., Jankauskiene, G., Ionita, I. 2012. effects of land use on annual runoff and soil loss in europe and the mediterranean: A meta-analysis of plot data. Progress in Physical Geography 36 (5), 599-653. https://doi. org/10.1177/0309133312451303.

Makeschin, F. 1997. Earthworms (Lumbricidae: Oligochaeta): Important promoters of soil development and soil fertility. In: G. Benckiser (ed.), Fauna in Soil Ecosystems, pp. 173-223.

Mann, H.B., Whitney, D.R. 1947. On a test of whether one of two random variables is stochastically larger than the other. The Annals of Mathematical Statistics 18 (1), 50-60. https://doi. org/10.1214/aoms/1177730491.

Marinissen, J.C.Y. 1992. Population dynamics of earthworms in a silt loam soil under conventional and 'integrated' arable farming during two years with different weather patterns. Soil Biology and Biochemistry 24 (12), 1647-1654. https://doi.org/10.1016/0038-0717(92)90164-S.

Marques, M.J., García-Muñoz, S., Muñoz-Organero, G., Bienes, R. 2010. Soil conservation beneath grass cover in hillside vineyards under Mediterranean climatic conditions (Madrid, Spain). Land Degradation and Development 21 (2), 122-31. https://doi.org/10.1002/ldr.915.

Martínez-Casasnovas, J.A. Ramos, M.C. 2009. Soil alteration due to erosion, ploughing and levelling of vineyards in north east Spain. Soil Use and Management 25 (2), 183-192. https:// doi.org/10.1111/j.1475-2743.2009.00215.x.

Molnár, D.K., Julien, P.Y. 1998. Estimation of upland erosion using GIS. Computers and Geosciences 24 (2), 183-192. https://doi.org/10.1016/S0098-3004(97)00100-3.

Novara, A., Gristina, L., Saladino, S.S., Santoro, A., Cerdà, A. 2011. Soil erosion assessment on tillage and alternative soil managements in a Sicilian vineyard. Soil and Tillage Research 117, 140-47. https://doi.org/10.1016/j.still.2011.09.007.

Panagos, P., Ballabio, C., Borrelli, P., Meusburger, K., Klik, A., Rousseva, S., Tadić, M.P., Michaelides, S., Hrabalíková, M., Olsen, P., Aalto, J., Lakatos, M., Rymszewicz, A., Dumitrescu, A., Beguería, S., Alewell, Ch. 2015a. Rainfall erosivity in Europe. Science of the Total Environment 511, 801-814. https://doi.org/10.1016/j.scitotenv.2015.01.008. 
Pijl et al.

Panagos, P., Borrelli, P., Meusburger, K. 2015b. A new European slope length and steepness factor (LS-Factor) for modeling soil erosion by water. Geosciences 5 (2), 117-126. https:// doi.org/10.3390/geosciences5020117.

Panagos, P., Borrelli, P., Meusburger, K., Alewell, C., Lugato, E., Montanarella, L. 2015c. Estimating the soil erosion cover-management factor at the European scale. Land Use Policy 48, 38-50. https://doi.org/10.1016/j.landusepol.2015.05.021.

Panagos, P., Borrelli, P., Meusburger, K., van der Zanden, E.H., Poesen, J., Alewell, C. 2015d. Modelling the effect of support practices (P-Factor) on the reduction of soil erosion by water at European scale. Environmental Science and Policy 51, 23-34. https://doi.org/10.1016/j. envsci.2015.03.012.

Panagos, P., Borrelli, P., Poesen, J., Ballabio, C., Lugato, E., Meusburger, K., Montanarella, L., Alewell, C. 2015e. The new assessment of soil loss by water erosion in Europe. Environmental Science and Policy 54, 438-447. https://doi.org/10.1016/j.envsci.2015.08.012.

Panagos, P., Meusburger, K., Ballabio, C., Borrelli, P., Alewell, C. 2014. Soil erodibility in Europe: A high-resolution dataset based on LUCAS. Science of the Total Environment 479480 (1), 189-200. https://doi.org/10.1016/j.scitotenv.2014.02.010.

Pellenc, R., Delran, R. 2000. Multipurpose machine for close-row production for tree or shrub plantations such as vineyards or orchards. US6840026B2, issued 2000.

Poesen, J.W.A., Hooke, J.M. 1997. Erosion, flooding and channel management in Mediterranean environments of southern Europe. Progress in Physical Geography 21 (2), 157-199. https:// doi.org/10.1177/030913339702100201.

Polge de Combret-Champart, L., Guilpart, N., Mérot, A, Capillon, A., Gary, C. 2013. Determinants of the degradation of soil structure in vineyards with a view to conversion to organic farming. Soil Use and Management 29 (4), 557-566. https://doi.org/10.1111/sum.12071.

Ramos, M.C., Benito, C., Martínez-Casasnovas, J.A. 2015. Simulating soil conservation measures to control soil and nutrient losses in a small, vineyard dominated, basin. Agriculture, Ecosystems and Environment 213, 194-208. https://doi.org/10.1016/j.agee.2015.08.004.

Ramos, M.C. 2016. Soil losses in rainfed mediterranean vineyards under climate change scenarios. The effects of drainage terraces. AIMS Agriculture and Food 1 (2), 124-143. https://doi. org/10.3934/agrfood.2016.2.124.

Ramos, M.C., Cots-Folch, R., Martínez-Casasnovas, J.A. 2007. Sustainability of modern land terracing for vineyard plantation in a mediterranean mountain environment - The case of the Priorat Region (NE Spain). Geomorphology 86 (1-2), 1-11. https://doi.org/10.1016/j. geomorph.2006.08.004.

Ramos, M.C., Porta, J. 1997. Analysis of design criteria for vineyard terraces in the mediterranean area of north east Spain. Soil Technology 10, 155-166. https://doi.org/10.1016/S09333630(96)00006-2.

Regione Veneto, 2016. Venetian terraced landscapes. In: F. Alberti, L. Lodatti (Eds.), Terraced Landscapes: Choosing the Future. Regione Veneto.

Renard, K.G., Foster, G.R., Weesies, G.A., McCool, D.K., Yoder, D.C. 1997. Predicting soil erosion by water: a guide to conservation planning with the Revised Universal Soil Loss Equation (RUSLE). U.S. Department of Agriculture, Agriculture Handbook. Vol. 703. Washington, DC. https://doi.org/DC0-16-048938-5 65-100.

Rodrigo-Comino, J. 2018. Five decades of soil erosion research in 'terroir'. The State-of-the-Art. Earth-Science Reviews 179, 436-447. https://doi.org/10.1016/j.earscirev.2018.02.014.

Savo, V., Caneva, G., McClatchey, W., Reedy, D., Salvati, L. 2014. Combining environmental factors and agriculturalists observations of environmental changes in the traditional terrace system of the Amalfi Coast (Southern Italy). Ambio 43 (3), 297-310. https://doi.org/10.1007/ s13280-013-0433-3. 
Schjønning, P., Elmholt, S., Munkholm, L.J., Debosz, K. 2002. Soil quality aspects of humid sandy loams as influenced by organic and conventional long-term management. Agriculture, Ecosystems and Environment 88 (3), 195-214. https://doi.org/10.1016/S01678809(01)00161-X.

Schrader, S., Lingnau, M. 1997. Influence of soil tillage and soil compaction on microarthropods in agricultural land. Pedobiologia 41 (1-3), 202-209.

Schreck, E., Gontier, L., Dumat, C., Geret, F., Schrader, S. 2012. Ecological and physiological effects of soil management practices on earthworm communities in French vineyards. European Journal of Soil Biology 52, 8-15. https://doi.org/10.1016/j.ejsobi.2012.05.002.

Sofia, G., Roder, G., Dalla Fontana, G., Tarolli, P. 2017. Flood dynamics in urbanised landscapes: 100 years of climate and humans' interaction. Scientific Reports 7, 40527. https://doi. org/10.1038/srpr.40527.

Steenwerth, K., Belina, K.M. 2008. Cover crops enhance soil organic matter, carbon dynamics and microbiological function in a vineyard agroecosystem. Applied Soil Ecology 40 (2), 359-369. https://doi.org/10.1016/j.apsoil.2008.06.006.

Stoate, C., Boatman, N.D., Borralho, R.J., Rio Carvalho, C., De Snoo, G.R., Eden, P. 2001. Ecological impacts of arable intensification in Europe. Journal of Environmental Management 63 (4), 337-365. https://doi.org/10.1006/jema.2001.0473.

Tarolli, P., Cavalli, M., Masin, R. 2019. High-resolution morphologic characterization of conservation agriculture. Catena 172,846-856. https://doi.org/10.1016/j.catena.2018.08.026.

Tarolli, P., Preti, F., Romano, N. 2014. Terraced landscapes: from an old best practice to a potential hazard for soil degradation due to land abandonment. Anthropocene 6, 10-25. https://doi. org/10.1016/j.ancene.2014.03.002.

Toth, G., Jones, A., Montanarella, L. 2013. The LUCAS topsoil database and derived information on the regional variability of cropland topsoil properties in the European Union. Environmental Monitoring and Assessment 185 (9), 7409-7425. https://doi.org/10.1007/s10661-013-3109-3.

Verheijen, F.G.A., Jones, R.J.A., Rickson, R.J., Smith, C.J. 2009. Tolerable versus actual soil erosion rates in Europe. Earth-Science Reviews 94 (1-4), 23-38. https://doi.org/10.1016/j. earscirev.2009.02.003.

Wischmeier, W.H., Smith, D.D. 1978. Predicting rainfall erosion losses: A guide to conservation planning. U.S. Department of Agriculture Handbook 537, 1-69. https://doi.org/10.1029/ TR039i002p00285. 


\section{Pijl et al}

\section{Supplementary material}

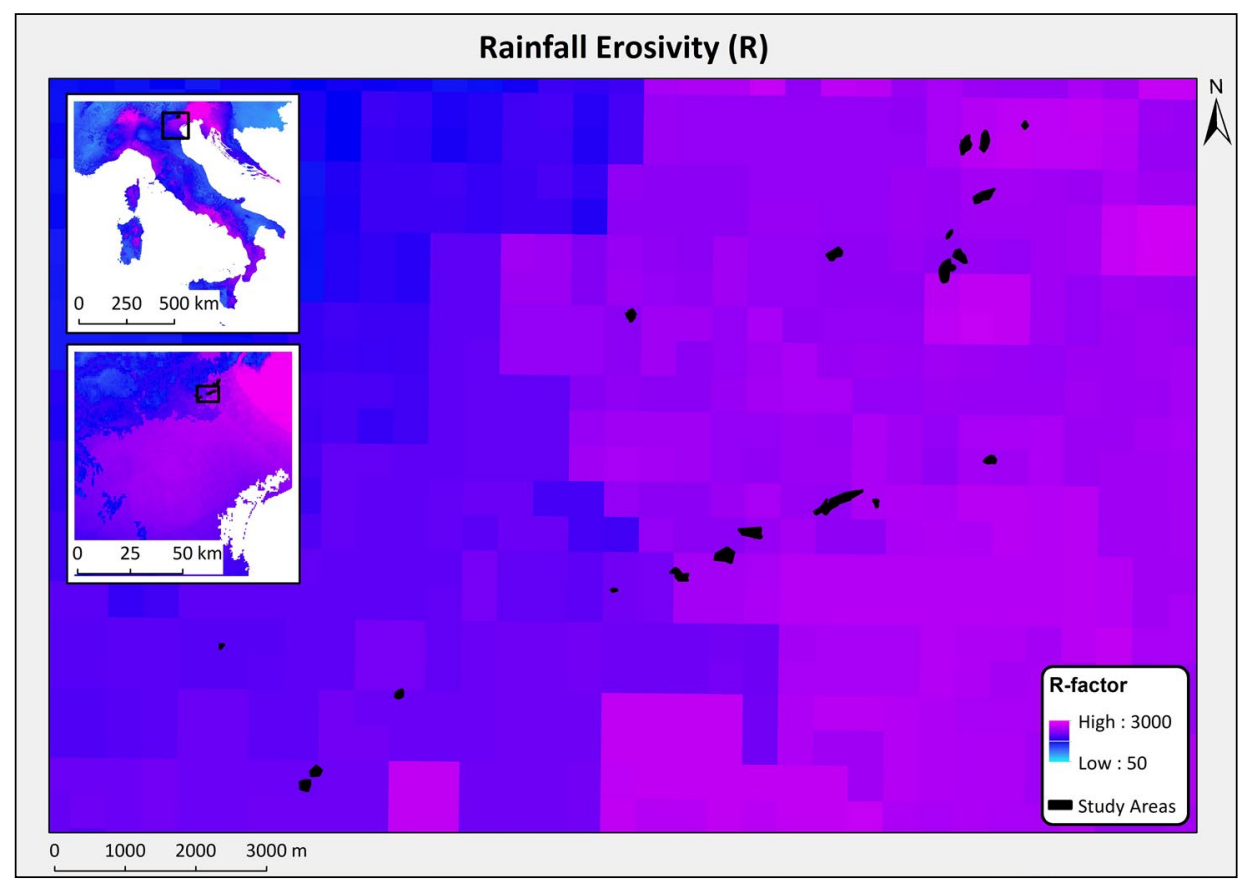

A. Rainfall erosivity map (grid-size 500m), based on a European application of RUSLE (Panagos et al., 2015a). 